ukrainian_in_donetsk_om [Accessed: 27th October 2016].

10. Lisnychuk $O$. Indocrination. In: Political encyclopedia. (2011). Redkol.: Yu. Levenets, Yu. Shapoval. - Kiev: Parlamentske vydavnytstvo, 287 p. [in Ukr.]

11. On Approval of the Concept of Implementation of the State Policy in the Field of General Secondary Education Reform "New Ukrainian School" for the Period till 2029. Osvita.UA [Online] Available from:
https://osvita.ua/legislation/Ser_osv/54258 [Accessed: 14th December 2016].

12. Pohribnyi A. (2000)Talk about painful, or If we were learning how it should be. - Kiev: Prosvita,. - 320 p. [in Ukr.]

13. Work programs [Online] Available from: http://school123.ucoz.net/index/rabochie_programmy/0-41 14. The share of Ukrainian students studying in Ukrainian. [Online] Available from: http://statistika.in.ua/mova2001/ukrainska_v_shkolah

Удк 377 (477)

\title{
Олена Газізова
}

\section{ПРОБЛЕМИ ЕТНОКУЛЬТУРНОГО ПРОСТОРУ АР КРИМ В КОНТЕКСТІ АНЕКСIÏ ПІВОСТРОВА}

\begin{abstract}
Анотація. В системі етнокультурних взаємин в АР Крим ключове місце посідає кримськотатарська проблема, зумовлена як низкою успадкованих від минулого факторів, так і недосконалістю законодавчої бази України, ї етнонаціональної політики. Сформована за роки незалежності політико-правова база створила підгрунтя для гармонійного поєднання інтересів усіх складових української політичної нації, однак вона недостатньо забезпечила рівні умови для етнонаціонального розвитку й активної участі у державотворчих процесах кримськотатарського народу та національних меншин.

За даними Всеукраїнського перепису населення України 2001 р., в Автономній Республіці Крим проживало 24,3 \% українців, 58,3\% - росіян, 12,0\% - кримських татар, 5,4 \% - інших національностей, зокрема, білорусів - 1,4 \%, татар 0,5 \% та ін. Окрема статистика по місту Севастополю свідчить про переважання російського населення (71,6 \%), майже середньостатистичний по Криму відсоток українців (22,4 \%) та про нечисельну кримськотатарську громаду $(0,5 \%)$.

За роки незалежності національно-культурні потреба українців і кримських татар задовольнялися вкрай погано. Так, з 583 шкіл, що фрункціонували у Криму в 2014 р., лише 7 були україномовними, а з 23,4\% школярів - етнічних українців - державною мовою навчалися лише 0,7 \%. У 2013/14 навчальному році рідною мовою здобували освіту 5551 кримськотатарська дитина, національно-культурні потреби кримських татар не задовольнялися повністю, кількість навчальних місць в кримськотатарських класах не відповідала реальним потребам. Однією з причин такої ситуації була відсутність кваліфікованих педагогічних кадрів, недостатнє забезпечення навчальною літературою тощо.

Після анексії Криму українська мова, яку окупаційна влада визнала однією із державних, майже повністю зникла з освітнього простору Криму, із 7 шкіл з українською мовою навчання залишилась тільки 1. У Республіці Крим продовжує фрункціонувати 15 загальноосвітніх закладів з кримськотатарською мовою навчання (201 клас, 3651 учень).

Виклики в гуманітарній сфері, зокрема упосліджене становище української мови в культурно-освітньому континуумі Криму, задовго до початку збройного конфрлікту на сході України та анексії АР Крим знаходилися у полі зору української гуманітаристики, провідні науковці вказували на негативні етнокультурні тенденції, викликані бездіяльністю органів державної влади, що підсилювали загрози дезінтеграції та втрати державного суверенітету. За роки незалежності України в Криму не було сформовано сильного проукраїнського електорату, здатного до відстоювання державного суверенітету. Враховуючи постійну підтримку Росією російської громади півострова, лобіювання ідеї «руського мира» та «исконно русского Крыма» і недостатню підтримку Україною української та кримськотатарської громад, які здатні були б протистояти сепаратистським загрозам, ідеологічна війна на теренах Криму була програна ще до 2014 р., що стало однією з причин анексії півострова.
\end{abstract}

Ключові слова: національна культура, АР Крим, анексія, українці, кримські татари, росіяни, гуманітарні виклики.

\section{Olena Hazizova}

\section{PROBLEMS OF ETHNOCULTURAL SPACE OF THE AR OF CRIMEA IN THE CONTEXT OF THE ANNEXATION OF THE PENINSULA}

Annotation. The Crimean Tatar problem holds a leading position in the system of ethnocultural relations with the AR of Crimea. It is caused by a number of factors inherited from the past, as well as by the imperfection of the legislative basis of Ukraine, its ethnonational policy. Political and legal foundation, built during the years of independence, made it possible to combine the interests of all components of the Ukrainian political nation; however, it didn't provide equal conditions for the ethnonational development and active participation in state-building processes of Crimean Tatars and national minorities.

According to the All-Ukrainian Population Census of 2001, the ethnic composition of the Autonomous Republic of Crimea is as follows: Ukrainians constitute $24.3 \%$, Russians $-58.3 \%$, Crimean Tatars $-12.0 \%$, other nationalities - $5.4 \%$ (Belarusians $1.4 \%$, Tatars $-0,5 \%$, etc.). Separate statistics regarding the city of Sevastopol indicated the prevalence of Russians (71.6\%); almost the statistically average percentage of Ukrainians in Crimea (22.4\%); and a small Crimean Tatar community (0.5\%).

During the years of independence, the national and cultural need of Ukrainians and Crimean Tatars to study in their mother tongues was extremely poor. So, out of 583 schools that functioned in Crimea in 2014, only 7 were Ukrainian, and from $23.4 \%$ of ethnically Ukrainian schoolchildren only $0.7 \%$ were taught in the state language. In the 2013-14 academic year, 5551 Crimean Tatar children were educated in their native language; the national-cultural needs of the Crimean Tatars were not completely 
satisfied, the number of classrooms and seats in the Crimean Tatar classes did not meet real needs. One of the reasons causing this situation was the lack of qualified pedagogical staff, lack of textbooks, etc.

After the annexation of Crimea, the Ukrainian language, which the occupation government had recognized as one of the state languages, almost completely disappeared from the educational space of Crimea, with only 1 of 7 schools retaining Ukrainian-language instruction. Today, 15 general education establishments of the Republic of Crimea continue to provide their instruction in the Crimean Tatar language (201 classes, 3651 students).

Long before the onset of the armed conflict in eastern Ukraine and the annexation of Crimea, challenges in the humanitarian field, in particular the tragedy of the Ukrainian language in the cultural and educational continuum of the peninsula, were in the sight of the Ukrainian humanities: lead scientists observed negative ethnocultural tendencies caused by the inaction of state authorities that reinforced the threat of disintegration and loss of state sovereignty. During the years of Ukrainian independence, Crimea hasn't formed strong pro-Ukrainian electorate capable of defending state sovereignty. Taking into account the constant support of Russia by the Russian community of the peninsula, lobbying for the idea of the "Russian World" and "the originally Russian Crimea", as well as the lame state support of Ukrainian and Crimean Tatar communities, which would be able to withstand the separatist threats, the ideological war in Crimea had been lost even before 2014, which became one of the reasons for the annexation of the peninsula.

Key words: national culture, AR of Crimea, annexation, Ukrainians, Crimean Tatars, Russians, humanitarian challenges.

Один із західних політологів колись писав, що етнос - це останній притулок людини. Коли руйнуються різні ідентичності - людина може втратити роботу, батьківщину, втратити все, що у неї $\epsilon,-$ але єдиним притулком, де людина дійсно може зустріти розуміння і захист завжди є етнічна група, де її приймуть, як рідного брата.

Метою нашої статті $є$ дослідження культурноосвітніх процесів в контексті етнокультурного розвитку етнічних громад Криму в період незалежності України та в умовах анексії півострова як проблемне поле гуманітарної політики України щодо загроз і викликів суверенітету держави.

На початку XXI ст. зусилля наявних наукових інституцій НАН України зосередилися на підготовці повноцінної етнополітичної історії Криму. Детально ця проблема розробляється в Інституті політичних та етнонаціональних досліджень ім. І.Ф. Кураса НАН України. Зокрема, в 2005 р. була опублікована монографія «Крим в етнополітичному вимірі» [15].

Культурно-освітню ситуацію Криму, на думку авторів дослідження, визначають три фрактори: поперше, специфрічні етнокультурні явища, ідеологічні стереотипи, успадковані від радянської системи, подруге, помітний вплив на культурно-освітній розвиток справило відновлення державної незалежності України і надання йому автономії; по-третє, новим чинником культурного і духовного життя Криму стало масове повернення татар та інших репресованих етносів на свою історичну батьківщину і зміна етнічного складу населення півострова [16, с. 476].

Значну увагу дослідженню культурно-освітніх проблем приділяє О. Калакура, який стверджує, що «вимогою часу стало приведення мережі освітніх установ регіону у відповідність до їі етнічного складу, включення культурно-освітніх процесів автономії в загальну орбіту етнокультурного життя України» [14, с. 509].

Проблема освітніх процесів у Криму кінця $X X-$ поч. XXI ст. перебуває в центрі уваги таких дослідників: П. Вольвача, В. Лукашенка, С. Кочерги. У своїх статтях П. Вольвач порушує питання про розвиток української культури, мови та освіти в Криму, наголошуючи на значенні україномовної освіти для становлення справжнього громадянина України, відповідального представника української нації. Внесок у фрормування нового, об'єктивного, уявлення про історію Криму і народів, які здавна населяють його, зробила праця В. Сергійчика «Український Крим» [24].

Основу джерельної бази статті становлять архівні матеріали Державного архіву Автономної Республіки Крим.

Одним із стратегічних пріоритетних завдань, судячи з офріційних документів, є розв'язання низки проблем гуманітарного розвитку автономії, посилення інтеграції півострова в загальноукраїнський контекст. Це зазначено в Указі Президента України «Про деякі заходи щодо розвитку гуманітарної сфери в Автономній Республіці Крим та місті Севастополі» від 20 листопада 2007 р. № 1122/2007. У законі йдеться про необхідність запровадження політики «популяризації української культури, задоволення національно-культурних потреб, всебічного розвитку та функціонування української мови в усіх сферах суспільного життя Автономної Республіки Крим та міста Севастополя» шляхом вжиття заходів в освітній та культурній сорерах щодо розширення мережі навчальних закладів усіх типів з українською мовою навчання й створення нових загальноосвітніх навчальних закладів з українською мовою навчання в населених пунктах Автономної Республіки Крим [4, с. 9]. На жаль, виконання цього закону, як і ряду інших щодо етнокультурного розвитку автономії гальмувалося.

За роки незалежності України етнічна конфігурація в АР Крим змінювалась у бік зменшення частки домінуючих етнічних груп (росіян і українців) та збільшення питомої ваги кримських татар. Представники інших етнічних груп складають сьогодні невелику частку кримського населення (вірмени, євреї, поляки, німці, греки, корейці, молдавани та інші).

За даними Всеукраїнського перепису населення України 2001 р., в Автономній Республіці Крим проживало 24,3 \% українців, 58,3\% - росіян, кримських татар - 12,0\%, представників інших національностей - 5,4 \%, зокрема, білорусів - 1,4\%, татар $-0,5 \%$ тощо [29, с. 19]. Окрема статистика по місту Севастополю свідчить про переважання російського населення $(71,6 \%)$, майже середньостатистичний по Криму відсоток українців 
$(22,4 \%)$ та нечисельну кримськотатарську громаду $(0,5 \%)$ [29, c. 19].

За рідною мовою населення Криму розподіляється так: українську як рідну визнають 10,1 \% населення, російську - 77,0\%, інші мови як рідні $12,9 \%$ (у тому числі кримськотатарську - 11,4\%) [2, c. 5].

Одним із механізмів, за допомогою яких здійснюється людська діяльність $€$ культурна традиція. Вона формується як соціальна форма передачі людського досвіду. Традиція пов'язана 3 усіма видами культури. Ї̈̈ можна розглядати у зв'язку з такими видами діяльності, як ідеологічна, цілісноорієнтаційна, політична. Така діяльність спрямована на формування і розвиток суспільної свідомості, на вироблення суспільних ідеалів. Характерно, що кожна 3 національних культурних традицій, представлених в АР Крим - українська, російська, кримськотатарська - має більше число тих, хто себе до неї відносить, ніж тих, хто вважає, що вона переважатиме у Криму через 20-25 років, причому така картина тією чи іншою мірою спостерігається в кожній із національно-етнічних груп. Понад половина $(55,5 \%)$ кримчан і понад дві третини $(66,7 \%)$ жителів Севастополя відносять себе до російської культурної традиції: відповідно 14,6 \% і 18,9 \% - до радянської, до української - 8,6 \% і 4,9\% [2, с. 9]. Кримськотатарська культурна традиція представлена у Криму відчутно більшою мірою (8,3\%), ніж у Севастополі $(0,7 \%)$ [2, с. 9]. За національною ознакою до російської культурної традиції відносять себе переважна більшість $(69,9 \%)$ росіян і відносна більшість $(43,5 \%)$ українців [2, с. 9]. До української традиції віднесли себе дещо більше п'ятої частини $(21,6 \%)$ українців і по 4 \% росіян та кримських татар [2, c. 9].

I серед українців, і серед росіян досить значним $є$ відсоток тих, хто асоціює себе з радянською культурною традицією - 16,5\% і $15 \%$ відповідно. Серед українців також порівняно значний відсоток $(10,7 \%)$ тих, хто відносить себе до загальноєвропейської культурної традиції (серед росіян $-6 \%$ ) [2, с. 9].

Натомість серед кримських татар абсолютна більшість $(84,2 \%)$ засвідчили свою прихильність кримськотатарській культурній традиції [2, с. 9]. Лише незначні частки представників цієї національної групи визнали свою належність до інших культурних традицій: приблизно по $4 \%$ - до російської, радянської та української, близько $3 \%$ - до загальноєвропейської [2, с. 9]. На думку кримчан, переважання російської культурної традиції в майбутньому буде зменшуватися, насамперед, на користь загальноєвропейської культурної традиції.

За інформацією Міністерства культури АРК станом на 1999 р. ситуація у культурно-освітньому секторі була наступною.

Кількість самодіяльних театрів - 265. 3 них: українських - 32, російських - 231, кримськотатарських - 2 [13]. Кількість самодіяльних хорових колективів - 689. 3 них - українських - 75, російських - 602, чеських - 2, білоруських - [13].

Кількість хореографрічних колективів - 523. 3 них російських - 482, кримськотатарських - 38, корейських - 2, німецьких - 1. Кількість музичних ансамблів - 448. 3 них українських - 7, російських 399, татарських - 42 [13].

Отже, як видно із статистичних даних, серед національних культурних осередків найбільша кількість - російських, при цьому із загальної кількості колективів - 1925, російських - 1714, що складає $89 \%$, українських - 114, що складає 5,9\%, кримськотатарських - 82, тобто лише 4,25\%, інших національно-етнічних груп - 7, що складає - 0,36\%.

Така ситуація не відповідала національному складу населення, була порушенням Конституції України та Конституції Автономної Республіки Крим.

Не кращим був і стан забезпечення рівних прав національно-етнічним групам Автономії щодо реалізації своїх культурно-освітніх потреб через засоби масової інформації: періодичні видання, телебачення та радіо.

Час трансляції національних редакцій на телебаченні складав - української - 4,4 години, кримськотатарської - 6, болгарської - 1,4, німецької 1,4, грецької - 1,4, вірменської - 1 .

Час трансляції радіоредакцій: української - 10 годин, кримськотатарської - 17, німецької - 1,2, єврейської - 1,2 [13].

Станом на 01.11.99 р. українською мовою видавалося 4 друкованих видання.

Кримське радіо транслює передачі «Ковчег», «Початок», «Два кольори»

Телерадіокомпанія «Крим» транслювала близько 4 годин на тиждень авторських програм «Просвіти», «Рідна хата», «Млин», «Відчуй життя», «Цікаві зустрічі» [13].

На жаль, з розвитком української державності, ситуація щодо забезпечення конституційного права на культурно-освітній розвиток національно-етнічних груп не покращувалася, а навпаки подекуди простежувалися тенденції до погіршення.

У 2002 р. в АР Крим виходило 575 друкованих періодичних видань. За мовою їх структура має такий вигляд: російською - 441; російською і українською 61; кримськотатарською - 28; іншими - 41 [16, с. 492].

Що ж стосується української преси, то в АР Крим видавались газета «Кримська світлиця» 3 трьома додатками (сумарний тираж 3 тис. примірників), «Дзвін Севастополя» (за підтримки «Просвіти») тиражем до 1000 примірників. У той же час загальний тираж російськомовних видань становив 3 млн. примірників. Вони повністю фрінансувалися з бюджету АР Крим.

Подібна ситуація і в телерадіопросторі. Тривалість україномовних передач на каналах телебачення i радіо постійно скорочувалася. Кількість працівників української редакції Державного радіомовлення з 20 чоловік у 1995 р. зменшилася до 6 чоловік у 2001 p. [16, с. 493]. 
Поділяємо точку зору І. Лосєва: «Сьогодні Автономна Республіка Крим $є$ фрактично російською національною автономією в Україні, де національнокультурні інтереси кримських татар і українців майже не представлені» [17]. І хоча це інформація станом на 2008 р., на жаль, вона була актуальною і на початок 2014 р., оскільки національно-культурні інтереси українців та кримських татар за роки незалежності України фрактично ігнорувалися українською владою, в той час як проросійські настрої посилювались. Комплекс меншовартості українців Криму посилювало бачення ними потужної підтримки, яку надавала Росія місцевим росіянам у сорері культури, мови, освіти, захисті національних прав тощо.

Постановою Ради Міністрів АРК від 27 серпня 1997 р. № 260 була затверджена «Програма розвитку мережі шкіл та класів з українською і кримськотатарською мовами навчання, шкіл і класів з двома мовами навчання на 1997-2006 рр.» Відповідно до цієї програми у всіх містах i районах Криму розроблені і затверджені рішеннями міськвиконкомів і райрад відповідні регіональні програми.

У результаті виконання цієї Постанови у 2,5 раза збільшилася кількість учнів, що навчаються кримськотатарською мовою ( з 1109 у 1996-1997 н. р. до 2408 у 1997-1998 н. р.), у 2,4 раза - число учнів, що начаються українською мовою (з 392 до 937). Навчання кримськотатарською мовою було організовано у 9 районах Криму, українською - у 8 із 25 [10].

За визначенням фрахівців Центру Разумкова, присутність у Криму української культури і мови (україномовних засобів масової інформації, закладів освіти і культури) була вкрай незадовільною. I це викликано не об'єктивними передумовами, як стверджують автори, а є наслідком діяльності певних антиукраїнських деструктивних сил, відсутністю в керівництві України політичної волі та потурання їхній місцевій владі [2, с. 28]. Тож і цілком закономірно, що з 583 шкіл, що функціонували у Криму в 2014 р., лише 7 були україномовними, а з 23,4\% школярів етнічних українців - державною мовою навчалися лише $0,7 \%$ [2, с. 28].

Голова Кримської організації УНП О. Фомушкін, коментуючи результати круглого столу в Сімферополі на тему «Стан української культури в Криму: реальність, проблеми, перспективи», заявив: «Кримська влада свідомо знищує в автономії українську культуру, перешкоджає розвитку української мови та освіти» [28]. Учасники заходу вимагали всебічного виконання Указу Президента України № 6/2009 від 12.01.2009р. «Про деякі невідкладні заходи щодо підтримки культури і духовності в Україні». Вони підготували звернення до Верховної Ради України з пропозицією прийняття Закону України «Про культуру», який буде передбачати державну підтримку українських закладів культури в автономії. Голова Кримської організації УНП О. Фомушкін справедливо зазначає:
«Фактично українська культура в Криму являє собою декоративний елемент...треба примусити Президента України, керівництво українського Уряду та Верховної Ради звернути увагу на стан української культури, мови та освіти в Криму та розробити комплексну програму з виходу їх з кризи» [28].

За час існування новітньої Української держави найбільш впливові кримськотатарські структури (Курултай і Меджліс) залишалися тією опорою української влади, яка допомагала їй протистояти сепаратистським проросійським рухам. М. Джемільов, глава Меджлісу кримськотатарського народу, 1 лютого 2007 р. зазначив: «Ми реалісти і прекрасно розуміємо, що в інтересах кримськотатарського народу бути у складі України. Так уже склалося в світі, що не може кожна національність мати свою державу. Тому у нас це цілком узгоджується. Ми є громадянами України. До речі кажучи, про кримських татар говорять, що вони основні українці в Криму, тому що вони - основна організована сила, яка активно протидіє сепаратиським тенденціям значної частини політиків російськомовної більшості в Криму. Ми намагаємося інтегруватися в українське суспільство, навчати своїх дітей української мови і зараз серед кримських татар значно більше тих, що володіють українською мовою, ніж, наприклад, серед російськомовного населення Криму. Але, зрозуміло, не меншого значення ми надаємо і збереженню своєї рідної мови, своєї національної культури та ідентичності» [27].

Однією 3 найактивніших та найчисельніших $\epsilon$ Республіканська асоціація кримськотатарських працівників освіти «Маарифчі» («Просвітитель»).

«Маарифчі» була зареєстрована в 1996 р. й відтоді вона тільки зміцнює свої позиції. Члени «Маарифчі» представлені в Курултаї кримськотатарського народу. Керівник асоціації С. Каджаметова - активний член Меджлісу, що лише додає ваги організації. С. Каджаметова однією 3 перших зрозуміла, що сила організації в іï поширеності, і створила мережу фрілій «Маарифчі» по всьому Криму. «С. Каджаметова впливає на вчителів і учнів національних шкіл та користується великою повагою серед батьків», - так охарактеризувала лідера асоціації кримська газета «Авдет» [28].

Головна мета «Маарифчі» - координація зусиль зацікавленої громадськості в справі становлення і розвитку освіти кримськотатарського народу в єдиній системі освіти Криму та України.

Незважаючи на те, що кримськотатарські громадські організації домоглися відкриття на півострові 15 шкіл 3 кримськотатарською мовою навчання, у 2013/14 н. р. рідною мовою здобували освіту 5551 кримськотатарська дитина, національно-культурні потреби кримських татар не задовольнялися повністю, кількість навчальних місць в кримськотатарських класах не відповідала реальним потребам. Однією з причин такої ситуації була відсутність кваліфікованих педагогічних 
кадрів, недостатнє забезпечення навчальною літературою тощо.

Після референдуму в березні 2014 р. почався перехід навчальних закладів Криму до освітніх стандартів Російської Федерації. На сайті Міністерства освіти, науки та молоді окупаційної влади розміщено інформацію щодо правового регулювання навчання рідною мовою. Зокрема, зазначено, що згідно зі статтею 14 федерального закону від 29.12.2012 р. № 273-Ф3 «Про освіту в Російській Федерації» громадяни Росії мають право на отримання дошкільної, початкової (1-4 класи) і основної загальної (5-9 класи) освіти на рідних мовах, а також право на вивчення рідних мов (1-11 класи) в межах можливостей, що надаються системою освіти [20].

Статтею 10 Конституції Республіки Крим від 11.04.2015 р. визначено, що державними мовами в Республіці Крим $є$ російська, українська і кримськотатарська. Стаття 19 Конституції Республіки Крим регламентує право кожного громадянина на користування рідною мовою, на вільний вибір мови спілкування, виховання, навчання і творчості [20].

Відповідно до частини 2 статті 11 Закону Республіки Крим від 06.07.2015 р. № 131-3РК / 2015 «Про освіту в Республіці Крим» реалізація прав громадян на навчання рідною мовою та вивчення рідних мов забезпечується створенням необхідної кількості відповідних освітніх організацій, класів, груп, а також умов для їх функціонування. Викладання і вивчення рідної мови мають державну акредитацію освітніх програм здійснюються відповідно до фредеральних і державних освітніх стандартів.

Однак українська мова, яку окупаційна влада визнала однією із державних, майже повністю зникла 3 освітнього простору Криму. Це підтверджує інформація підконтрольного Росії Міністерства освіти, науки й молоді Криму, у поточному навчальному році функціонує 1 загальноосвітній заклад з українською мовою навчання (9 класів, 132 учні): Муніципальна бюджетна освітня установа «Школа № 20» м. Феодосії, крім того, на базі загальноосвітніх навчальних закладів з російською мовою навчання відкриті класи з українською мовою навчання (в 12 школах 19 класів, 239 учнів). Отже, станом на 1 вересня 2016 р. на території АР Крим середню освіту українською мовою отримувала тільки 371 дитина (0,2 \%) [18].

Це підтверджується у доповіді Верховного комісара ООН з прав людини: «Етнічні українці втратили можливість навчатися рідною мовою у Криму після анексії півострова і введення освітніх стандартів Російської Федерації» [26].

19 квітня 2017 р. Міжнародний суд ООН за позовом України проти Російської Федерації виніс постанову про тимчасові заходи, одноголосно ухваливши, що Російська Федерація має «забезпечити доступ до освіти українською мовою».

В ООН вважають, що головними причинами цього є переважно російське культурне середовище і виїзд тисяч проукраїнських жителів Криму на материкову частину України [26].

Насправді, однією 3 причин зникнення україномовного навчання в Криму стала відсутність підручників та навчальних посібників 3 предметів навчального плану українською мовою. А підручники материкової України потрапили під сувору заборону.

У доповіді ООН вказується, що кількість учнів, які навчаються кримськотатарською мовою, залишилася незмінною, в «основному завдяки високому рівню культурної самосвідомості серед кримських татар» [26].

У Республіці Крим продовжує функціонувати 15 загальноосвітніх закладів з кримськотатарською мовою навчання (201 клас, 3651 учень) [18]. На базі загальноосвітніх навчальних закладів 3 російською мовою навчання відкриті класи 3 кримськотатарською мовою навчання (в 37 школах 137 класів 1730 учнів) [18].

Також в школах Республіки Крим організовано вивчення рідних мов в різних формах (як предмет, фракультативно, в позаурочній діяльності): кримськотатарську мову вивчають 19254 учні, українську - 12892, вірменську - 54, болгарську - 62, новогрецьку - 136, німецьку - 56 [18].

Експерти Кримської правозахисної групи стверджують, що при збережених школах кількість кримськотатарських класів у них за три роки після анексії зменшилася на 10\%. Згідно з новим Законом про освіту після п'ятого класу навчання має відбуватися лише державною мовою 3 вивченням мови меншин як предмета [26].

Підсумовуючи дослідження, ми зазначаємо, що виклики в гуманітарній сфрері, зокрема упосліджене становище української мови в культурно-освітньому континуумі Криму, задовго до початку збройного конфлікту на сході України та анексії АР Крим знаходилися у полі зору української гуманітаристики, провідні науковці вказували на негативні етнокультурні тенденції, викликані бездіяльністю органів державної влади, що підсилювали загрози дезінтеграції та втрати державного суверенітету. За роки незалежності України в Криму не було сформовано сильного проукраїнського електорату, здатного до відстоювання державного суверенітету. Враховуючи постійну підтримку Росією російської громади півострова, лобіювання ідеї «руського мира» та «исконно русского Крыма» і недостатню підтримку Україною української та кримськотатарської громад, які здатні були б протистояти сепаратистським загрозам, ідеологічна війна на теренах Криму була програна ще до 2014 р. Українці як титульна нація не отримували державної підтримки у вирішенні культурно-освітніх потреб.

1. «Анексована» освіта в тимчасово окупованому Криму. Моніторинговий звіт / Укр. незалеж. центр політ. дослідж.: за заг. ред. Ю. Тищенко, О. Смірнова. - К.: Агентство «Україна», 2015. - 40 с. 
2. АР Крим: люди, проблеми, перспективи // Національна безпека й оборона. - 2008. - № 10. - 88 с.

3. «В Крыму стали говорить на российском русском» - интервью ректора КРИППО А. Н. Рудякова «Русской планете» [Електронний ресурс]. Режим доступу: http://krippo.ru/home/3-2012-06-10-1655-56/534-2015-04-06-15-01-11

4. Газізова О. Тенденції та перспективи розвитку національної освіти в Криму: українознавчий вимір / Газізова Олена // Українознавство. - 2010. - № 1. C. $9-103$

5. Виклики та загрози гуманітарній безпеці Української держави: зб. наук.-експ. мат-лів / за заг. ред. С.І. Здіорука. - К.: НІСД, 2015. - 104 с.

6. Вольвач П. Гордіїв вузол україномовної освіти в Криму / Петро Вольвач // Кримська світлиця. 2007. - № 7.

7. Вольвач П. Кримські аномалії (хто навчає і кого виховують у кримських вузах?) / Петро Вольвач // Українознавство. - 2003. - № 1. - С. 201.

8. Вольвач П. Українська провесінь Криму (Політична і громадська публіцистика) / П. В. Вольвач. - Кримський Незалежний центр політичних дослідників і журналістів; Комітет 3 моніторингу свободи преси в Криму; Кримська фрілія Наукового Товариства ім. Т. Шевченка; Видавництво «Доля». Сімферополь, 2008. - 359 с.

9. Гнаткевич Ю. Українська мова в Україні має виконувати об'єднавчу роль / Ю.Гнаткевич // Національна безпека й оборона. - 2008. - № 10. - С. 75.

10.Державний архів в Автономній Республіці Крим. - Ф. Р-4973. - Оп. 1. - Спр. 472. - Арк. 113.

11.Державний архів в Автономній Республіці Крим. - Ф. Р-4973. - Оп. 1. - Спр. 589. - Арк. 214.

12.Державний архів в Автономній Республіці Крим. - Ф. Р-4973. - Оп. 1. - Спр. 524. - Арк. 192.

13.Державний архів в Автономній Республіці Крим - Ф. Р-4973. - оп.1, спр. 589. - арк. 214

14.Калакура О. Культурно-освітнє відродження етносів в АРК: надбання і перспективи / О. Калакура // Проблеми інтеграції кримських репатріантів в українське суспільство. - К., 2004. - С. 509-522.

15.Курінний О. Мовно-культурний конфрлікт України: регіональний аспект / О. Курінний // Українознавство. - 2007. № 4 - С. 64-68.

16.Крим в етнополітичному вимірі / Редкол.: І. Курас (голова). Авт. кол.: М. Панчук (керівник), Г. Бекірова, В. Ганкевич та ін. - К., 2005. - 533 с.

17.Лосєв Ігор. Крим легендарний і реальний [Електронний ресурс]. - Режим доступу: http://www.radiosvoboda.org/a/1197250.html

18.0 состоянии образования на государственных (крымскотатарский, украинский) языках и изучение родных языков в образовательных организациях Республики Крым [Електронний ресурс]. - Режим доступу: http://monm.rk.gov.ru/rus/info.php?id=652570

19.Освітні центри Крим-Україна [Електронний ресурс]. - - Режим доступу: http://mon.gov.ua/content/\%D0\%9D\%D0\%BE\%D0\%B2
\%D0\%B8\%D0\%BD\%D0\%B8/2017/08/21/krim-ukrayinaonovlenij-21082017.pdf.

20.Правовое регулирование обучения на родных языках и изучения родных языков [Електронний ресурс]. - - Режим доступу: http://monm.rk.gov.ru/rus/info.php?id=652570

21.Примерные программы по украинскому язику [Електронний ресурс]. - Режим доступу: http://monm.rk.gov.ru/rus/info.php?id=652570

22. «Росія розглядає російську мову як елемент залучення до «русского міра» - Леонов [Електронний ресурс]. - - Режим доступу: https://ua.krymr.com/a/28766043.html

23.Росія робить тільки видимість навчання дітей у Криму кримськотатарською [Електронний ресурс]. Режим доступу: https://ua.censor.net.ua/n455292

24.Сергійчук В. Український Крим. Видання третє, доповнене / В. Сергійчук. - Вишгород: ПП Сергійчук M. I., 2016. -362 c.

25.Список учебных изданий, подготовленных и изданных АО «Издательство «Просвещение» по заказу Министерства образования, науки и молодежи Республики Крым в 2015-2016 годах [Електронний ресурс]. - - Режим доступу: http://monm.rk.gov.ru/rus/info.php?id=652570

26.Управління Верховного комісара Організації Об'єднаних Націй 3 прав людини. Тематична доповідь «Ситуація з правами людини в тимчасово окупованих Автономній Республіці Крим та місті Севастополі (Україна)» [Електронний ресурс]. Режим доступу: http://www.ohchr.org/Documents/Countries/UA/Crimea2 014_2017_Ukrainian.pdf

27.Украинский язык в Крыму: статус изгоя [Електронний ресурс]. - Режим доступу: https://ru.krymr.com/a/28757474.html

28. Центр інформації та документації кримських татар [Електронний ресурс]. - Режим доступу: http://www.crimeatau.org.ua.

29.Этническая история Крыма в таблицах, картосхемах и диаграммах (по данным переписей населения): информационно-справочное пособие./ Автор-сост. А. С. Петроградская. - Симферополь: АнтиквА, 2007. - 20 с., 5 карт.

\section{References}

1. "Annexed" Education in Temporarily Occupied Crimea. Monitoring Report (2015). In: Yu. TYSHCHENKO, O. SMIRNOVA, eds., Ukrainian Center for Independent Political Research. Kyiv: Ahentstvo "Ukraina", 40 p. [in Ukr.]

2. AR of Crimea: People, Problems, Prospects (2008). Natsionalna bezpeka i oborona, (10), 88 p. [in Ukr.]

3. "They Began Speaking Russian in Crimea" - an Interview with A.Rudiakov, Rector of Crimean Republican Institute of Post-Graduate Pedagogical Education. [online]. Available at: http://krippo.ru/home/32012-06-10-16-55-56/534-2015-04-06-15-01-11 [in Rus.]

4. Gazizova O. Tendencies and prospects for the development of nationality in Krima: Ukrainian-language 
vimir / Gazizova Olena // Ukrayinoznavstvo. - 2010. - \# 1. - S. 9-103.

5. Challenges and Threats to the Humanitarian Security of the Ukrainian State. (2015). In: S. ZDIORUK, ed., Zbirnyk naukovo-ekspertnykh materialiv. (Collected Scientific-Expert Materials). Kyiv: National Institute for Strategic Studies Press, 104 p. [in Ukr.]

6. VOLVACH, P. (2007). The Gordian Knot of Ukrainian-Language Education in Crimea. Krymska svitlytsia, (7). [in Ukr.]

7. VOLVACH, P. (2003). Crimean Anomalies (Who Teaches and Who Is Brought Up in Crimean Schools). Ukrainoznavstvo (Ukrainian Studies), Vol. 1, p. 201. [in Ukr.]

8. VOLVACH, P. (2008). Ukrainian Spring in Crimea (Political and Civil Journalism). In: Crimean Center of Independent Researchers and Journalists; Freedom of Press Monitoring Committee in Crimea; Crimean Branch of T. Shevchenko Scientific Society. Simferopol: Dolia, 359 p. [in Ukr.]

9. HNATKEVYCH, Yu. (2008). Ukrainian Language Must Play a Uniting Role in Ukraine. Natsionalna bezpeka i oborona, (10), p. 75. [in Ukr.]

10.State Archives of the Autonomous Republic of Crimea. [in Ukr.]

11. State Archives of the Autonomous Republic of Crimea. [in Ukr.]

12. State Archives of the Autonomous Republic of Crimea. [in Ukr.]

13. State Archives of the Autonomous Republic of Crimea. [in Ukr.]

14. KALAKURA, O. (2004). Cultural and Educational Renaissance of Ethne in the AR of Crimea: Achievements and Prospects. In: Problemy intehratsii krymskykh repatriantiv $v$ ukrayinske suspilstvo. (Problems of Integrating Crimean Repatriates into the Ukrainian Society). Kyiv, pp. 509-522. [in Ukr.]

15.KURINNYI, O. (2007). Linguocultural Conflict in Ukraine: Regional Aspect. Ukrainoznavstvo (Ukrainian Studies), Vol. 4, pp. 64-68. [in Ukr.]

16.KURAS, I., ed., PANCHUK, M., BERIKOVA, H., HANKEVYCH, V., et. al. (2005). Crimea in Ethnopolitical Dimension. Kyiv, 533 p. [in Ukr.]

17.LOSIEV, I. Legendary and Real Crimea. [online]. Available http://www.radiosvoboda.org/a/1197250.html [in Ukr.]

18. On the Condition of Education in the State Languages (Crimean Tatar, Ukrainian) and Studying Mother Tongues at Educational Institutions of the Republic of Crimea. [online]. Available at: http://monm.rk.gov.ru/rus/info.php?id=652570 [in Rus.]
19.Crimea-Ukraine Educational Centers. [online]. Available at: http://mon.gov.ua/tsontent/\%D0\%9D\%D0\%BE\%D0\%B2 \%D0\%B8\%D0\%BD\%D0\%B8/2017/08/21/krim-ukrayinaonovlenij-21082017.pdf. [in Ukr.]

20.Legal Regulation of Mother Tongue Teaching and Studying. [online]. Available at: http://monm.rk.gov.ru/rus/info.php?id=652570 [in Rus.]

21.Provisional Curricula for Teaching Ukrainian Language. [online]. Available at: http://monm.rk.gov.ru/rus/info.php?id=652570 [in Rus.]

22. "Russia Considers Russian Language as an Element for Involvement in the 'Russian World', 'Leonov. [online]. Available at: https://ua.krymr.tsom/a/28766043.html [in Ukr.]

23. Russia only Pretends to Teach Children in Crimea in the Crimean Tatar Language. [online]. Available at: https://ua.tsensor.net.ua/n455292 [in Ukr.]

24.SERHIICHUK, V. (2016). Ukrainian Crimea. $3^{\text {rd }}$ ed., expanded. Vyshhorod: M. Serhiichuk, 362 p. [in Ukr.]

25. The List of Textbooks Prepared and Published by "Prosveshcheniye" Publishing House JSC on Order of the Republic of Crimea Ministry of Education, Science, and Youth in 2015-2016. [online]. Available at: http://monm.rk.gov.ru/rus/info.php?id=652570 [in Rus.]

26.UN Office of the High Commissioner for Human Rights. Thematic Report "Human Rights Situation in the Temporarily Occupied Autonomous Republic of Crimea and the City of Sevasopol (Ukraine)" [online]. Available at: http://www.ohchr.org/Dotsuments/Tsountries/UA/Tsrimea 2014_2017_Ukrainian.pdf [in Ukr.]

27. Ukrainian Language in Crimea: Outlaw Status. [online]. Available at: https://ru.krymr.tsom/a/28757474.html [in Rus.]

28. Crimean Tatars' Information and Records Center. [online]. Available at: http://www.tsrimeatau.org.ua. [in Ukr.]

29.PETROGRADSKAYA, A. (2007). Ethnic History of Crimea in Tables, Sketch Maps, and Diagrams (After the Data of Population Censes): Information Guide. Simferopol: AntikvA, 20 p., 5 maps. [in Rus.] 